\title{
“ANALISIS PROFITABILITAS, LIKUIDITAS, AKTIVITAS, DAN SOLVABILITAS UNTUK MENGUKUR KINERJA KEUANGAN PADA PT.PEGADAIAN (PERSERO) CABANG TALASALAPANGDI KOTA MAKASSAR " \\ MAKASSAR \\ FEBRIANTI ANGELINA MAALUAS \\ (angelinamaaluas9052@gmail.com)
}

Institut Bisnis dan Keuangan Nitro Makassar Jl. Prof Abdurahman Basalamah No. 101 90231

\begin{abstract}
ABSTRAK
Penelitian ini bertujuan untuk menguji analisis rasio profitabilitas, rasio likuiditas, rasio aktivitas, dan rasio solvabilitas dalam menilai kinerja keuangan pada PT. Pegadaian (Persero) Cabang Talasalapang Di Kota Makassar. Metode yang digunakan dalam penelitian ini adalah analisis deskriptif yaitu untuk menjelaskan tentang hasil perhitungan rasio keuangan yang terdiri dari rasio profitabilitas, rasio likuiditas, rasio aktivitas, dan rasio solvabilitas yang terjadi dalam perusahaan selama tahun 2011 sampai dengan 2015. Pengumpulan data dilakukan dengan teknik wawancara dan dokumentasi. Populasi dalam penelitian ini adalah laporan keuangan PT. Pegadaian (Persero) Cabang Talasalapang Di Kota Makassar selama lima tahun terakhir (2015-2019) sekaligus menjadi sampel pada penelitian ini.

Hasil penelitian menunjukkan bahwa PT. Pegadaian (Persero) Cabang Talasalapang Di Kota Makassar selama lima tahun terakhir mengalami peningkatan, pengukuran kinerja keuangan dengan menggunakan rasio profitabilitas yang terdiri dari Return on Assets dinilai dalam keadaan yang baik karena kemampuan aktiva yang diinvestasikan untuk berputar dalam menghasilkan laba sangat tinggi dan dengan Return on Equity dinilai dalam keadaan yang baik karena kemampuan ekuitas/modal yang
\end{abstract}


digunakan untuk menghasilkan laba sangat tinggi. Pengukuran kinerja keuangan dengan menggunakan rasio likuiditas yang terdiri dari Current Ratio dinilai sangat baik karena kemampuan perusahaan dalam melunasi hutang lancar lebih dari $200 \%$ sedangkan dengan Quick Ratio selama tahun 2015-2019 mengalami fluktuasi, nilai ini dianggap masih aman. Nilai Quick Ratio yang diperoleh lebih dari 100\%, yang menunjukkan kemampuan perusahaan untuk melunasi hutang lancar dengan aktiva lancar setelah dikurang persediaan dalam kondisi baik. Pengukuran kinerja keuangan menggunakan rasio solvabilitas dengan Total Assets to Debt Ratio menunjukkan fluktuasi dari tahun 2015-2019 dan dapat dikatakan solvabel karena kemapuan perusahaan dalam memenuhi semua hutang dengan aktiva dapat terpenuhi, meskipun dalam tiga tahun terakhirnya mengalami penurunan.

Kata Kunci : Analisis Rasio, Profitabilitas, Likuiditas, Aktivitas, Solvabilitas. 


\section{PENDAHULUAN}

\section{A. Latar Belakang}

Perkembangan posisi keuangan mempunyai arti yang sangat penting bagi perusahaan. Untuk melihat sehat tidaknya suatu perusahaan tidak hanya dapat dinilai dari keadaan fisiknya saja, Misalnya dilihat dari gedung, pembangunan atau ekspansi. Faktor terpenting untuk dapat melihat perkembangan suatu perusahaan terletak dalam unsur keuangannya, karena dari unsur tersebut juga dapat mengevaluasi apakah kebijakan yang ditempuh suatu perusahaan sudah tepat atau belum, mengingat sudah begitu kompleksnya permasalahan yang dapat menyebabkan kebangkrutan dikarenakan banyaknya perusahaan yang akhirnya gulung tikar karena faktor keuangan yang tidak sehat.

Salah satu alat yang digunakan untuk mengetahui kondisi keuangan perusahaan dapat berwujud laporan keuangan. Laporan keuangan menyajikan gambaran mengenai posisi keuangan dari kinerja perusahaan dalam menghasilkan laba. Posisi keuangan perusahaan ditunjukkan dalam laporan neraca, dalam laporan neraca kita dapat mengetahui kekayaan atau assets perusahaan yang dimiliki (sisi aktiva), dan dari sisi pasiva dapat kita ketahui darimana dana-dana untuk membiayai aktiva tersebut (dari modal sendiri atau hutang), sedangkan kinerja perusahaan dalam menghasilkan laba dapat kita lihat dari laporan laba rugi perusahaan.

Analisis laporan keuangan merupakan proses yang penuh pertimbangan dalam 
rangka membantu mengevaluasi posisi keuangan dan hasil operasi perusahaan pada masa sekarang dan masa lalu, dengan tujuan untuk menentukan eliminasi dan prediksi yang paling mungkin mengenai kondisi dan kinerja perusahaan pada masa mendatang. Analisis terhadap laporan keuangan suatu perusahaan pada dasarnya untuk mengetahui tingkat profitabilitas, tingkat solvabilitas, tingkat likuiditas dan stabilitas usaha, dan tingkat resiko atau tingkat kesehatan suatu perusahaan.

Muslich (2003:47) menyatakan bahwa "analisis rasio keuangan merupakan alat utama dalam analisis keuangan, karena analisis ini dapat digunakan untuk menjawab berbagai pertanyaan tentang keadaan perusahaan". Tujuannya adalah memberi gambaran mengenai kelemahan dan kemampuan finansial Iperusahaan dari tahun ke tahun. Analisis rasio ini akan sangat membantu dalam menilai prestasi manajemen di masa lalu dan prospeknya di masa yang akan datang.

Selain manajemen yang baik, dalam suatu perusahaan juga memerlukan sebuah analisis terhadap laporan keuangan untuk mengetahui kemampuan perusahaan dalam mengatasi masalah-masalah keuangan perusahaan serta mengambil keputusan yang cepat dan tepat. Melalui analisis rasio laporan keuangan, manajemen dapat mengetahui posisi keuangan, kinerja keuangan dan kekuatan keuangan (financial strength) yang dimiliki perusahaan.Analisis rasio laporan keuangan yang lazim digunakan antara lain analisis rasio profitabilitas, analisis likuiditas dan rasio solvabilitas.

Analisis rasio profitabilitas menurut Saragih F, (2013) merupakan rasio yang digunakan dalam penilaian kinerja keuangan dalam menghasilkan laba dalam 
periode tertentu dan bertujuan untuk mengukur tingkat efektifitas manajemen dalam menjalankan operasional perusahaannya.

Analisis rasio likuiditas, menurut Saragih.F, (2013) merupakan rasio yang digunakan untuk mengukur kemampuan perusahaan dalam memenuhi kewajiban jangka pendek perusahaan.Analisis rasio likuiditas ini dapat digunakan pihak intern perusahaan untuk menjaga tersedianya alat - alat likuid, untuk membiayai operasionalnya dan untuk memenuhi kewajiban finansial yang harus segera dipenuhi. Sedangkan bagi pihak ekstren hal tersebut dapat dijadikan bahan pertimbangan dalam mengambil keputusan bisnis terhadap perusahaan tersebut.

Analisis rasio solvabilitas, menurut Saragih.F,(2013) merupakan rasio untuk mengukur kemampuan perusahaan dalam memenuhi kewajiban jangka panjang perusahaan.Informasi dari analisa rasio solvabilitas sangat berguna terutama bagi kreditur yang akan memberikan pinjaman kepada perusahaan sebagai informasi untuk memastikan apakah pihak kreditur dapat menarik kembali dana yang telah dipinjamkan kepada perusahaan tersebut apabila perusahaan dilikuidasi.

PT. Pegadaian (Persero) yang sebelumnya berbentuk badan usaha PERUM ini merupakan salah satu dari Badan Usaha Milik Negara. Sampai saat ini, PT Pegadaian (Persero) adalah lembaga formal di Indonesia yang berdasarkan hukum yang diperbolehkan melakukan pembiayaan dengan bentuk penyaluran kredit atas dasar hukum gadai. Pegadaian merupakan badan usaha yang bergerak dibidang pelayanan jasa pegadaian kepada rakyat. Dalam menjalankan aktivitasnya 
Pegadaian cabang Talasalapang Di Kota Makassar menggunakan dana yang cukup besar dimana dalam pengelolaannya diperlukan data yang lengkap sebagai dasar pengambilan keputusan yang baik terutama untuk mengetahui kemampuan perusahaan dalam memperoleh keuntungan selama melakukan kegiatan operasinya

\section{B. Rumusan Masalah}

Berdasarkan latar belakang masalah yang telah diuraikan di atas, maka peneliti merumuskan masalah yang akan dibahas dalam penelitian ini, yaitu

"Bagaimana penilaian kinerja keuangan pada PT. Pegadaian (Persero) Cabang Talasalapang Di Kota Makassar jika dilihat dengan menggunakan rasio profitabilitas, rasio solvabilitas, rasio aktivitas, dan rasio likuiditas.?"

\section{Tujuan Penelitian}

Tujuan dilakukan penelitian ini adalah untuk menguji analisis rasio likuiditas, rasio aktivitas, rasio solvabilitas, dan rasio profitabilitas dalam menilai kinerja keuangan pada PT. Pegadaian (Persero) Cabang Talasalapang Di Kota Makassar.

\section{Manfaat Hasil Penelitian}

a. Bagi peneliti, untuk lebih memahami prosedur analisis rasio keuangan dalam menilai kinerja keuangan,

b. Bagi pegadaian, sebagai informasi dan sebagai pertimbangan dalam menentukan keuangan dimasa yang akan datang, khususnya dalam laporan keuangan,

c. Bagi peneliti selanjutnya, sebagai bahan referensi bagi calon peneliti yang berminat melakukan penelitian menyangkut masalah yang dibahas. 


\section{TINJAUAN PUSTAKA}

\section{A. LANDASAN TEORI}

\section{Laporan Keuangan}

\section{a. Pengertian Laporan Keuangan}

Laporan keuangan adalah catatan informasi keuangan suatu perusahaan pada suatu periode akuntansi yang dapat digunakan untuk menggambarkan kinerja perusahaan. Laporan keuangan adalah bagian dari proses pelaporan keuangan. Kondisi keuangan suatu perusahaan akan dapat diketahui dari laporan keuangan perusahaan yang bersangkutan, yang terdiri dari neraca, laporan laba rugi serta laporan keuangan lainnya.

Menurut Munawir (2007:2) "pengertian laporan keuangan adalah hasil dari proses akuntansi yang dapat digunakan sebagai alat untuk berkomunikasi antara data keuangan atau aktivitas suatu perusahaan dengan pihak-pihak yang berkepentingan dengan data atau aktivitas perusahaan tersebut".

Kasmir (2008:7) "berpendapat bahwa laporan keuangan adalah laporan yang menunjukkan kondisi keuangan perusahaan pada saat ini atau dalam suatu periode tertentu. Laporan keuangan dapat digunakan untuk berbagai tujuan”. Data laporan keuangan terutama akan memberikan informasi bagi manajemen sebagai bahan analisis dan bahan interprestasi untuk mengadakan evaluasi terhadap aktivitas perusahaan. Laporan keuangan akan menunjukkan sampai seberapa jauh efisiensi pelaksanaan kegiatan serta perkembangan perusahaan yang telah dicapai oleh manajemen.

Berdasarkan beberapa pendapat tersebut di atas dapat disimpulkan bahwa 
laporan keuangan merupakan daftar untuk mengetahui jumlah kekayaan perusahaan pada periode tertentu, dalam bentuk neraca dan laporan laba rugi. Dipandang dari sudut pandang yang berkepentingan, ada tiga jenis laporan keuangan, yaitu laporan keuangan untuk manajmen, laporan keuangan untuk pihak eksternal perusahaan, dan laporan keuangan untuk pihak-pihak khusus. Laporan keuangan untuk ketiga pihak tersebut disusun dan disajikan dari suatu proses akuntansi yang sama, yaitu merupakan produk dari sebuah system informasi akuntansi.

\section{b. Tujuan Laporan Keuangan}

Secara umum laporan keuangan bertujuan untuk memberikan informasi keuangan suatu perusahaan, baik pada saat tertentu maupun pada periode tertentu. Laporan keuangan juga dapat disusun secara mendadak untuk kebutuhan perusahaan maupun secara berkala (rutin).

Menurut Standar Akuntansi Keuangan (2004:4) tujuan laporan keuangan sebagai berikut:

1. Menyediakan informasi yang menyangkut posisi keuangan, kinerja serta perubahan posisi keuangan suatu perusahaan yang bermanfaat bagi sejumlah pihak dalam pengambilan keputusan ekonomi.

2. Laporan keuangan juga menunjukkan apa yang dilakukan manajemen atas sumber daya yang dipercayakan kepadanya.

Sedangkan menurut Kasmir (2010:87) beberapa tujuan pembuatan laporan keuangan yaitu:

1.Memberikan informasi tentang jenis dan jumlah aktiva yang dimiliki 
perusahaan saat itu.

2. Memberikan informasi tentang jenis dan jumlah kewajiban dan modal yang dimiliki perusahaan saat itu.

3. Memberikan informasi tentang jenis dan jumlah pendapatan yang diperoleh pada suatu periode tertentu.

4. Memberikan informasi tentang jumlah biaya dan jenis biaya yang dikeluarkan perusahaan dalam suatu periode tertentu.

5. Memberikan informasi tentang perubahan yang terjadi terhadap aktiva, pasiva dan modal perusahaan

6. Memberikan informasi tentang kinerja manajemen perusahaan dalam suatu periode tertentu.

7. Memberikan informasi tentang catatan atas laporan keuangan dan informasi keuangan lainnya.

\section{c. Isi Laporan Keuangan}

Laporan keuangan yang disusun oleh pihak manajemen menurut Standar Akuntansi Keuangan No.1 (2002:13), terdiri dari:

1. Neraca (Balance Sheet)

2. Laporan Laba-Rugi (Income Statement)

3. Laporan Arus Kas (Statement of Cash Flow)

4. Laporan Perubahan Ekuitas (Statement of Change in Equity)

5. Catatan atas Laporan Keuangan (Notes to Financial Statement)

\section{d. Manfaat Laporan Keuangan}

Laporan keuangan merupakan alat yang sangat penting untuk mendapatkan 
informasi sehubungan dengan posisi keuangan dan hasil-hasil yang dicapai oleh perusahaan, serta sebagai alat manajemen untuk mempertanggungjawabkan kepada para pamilik perusahaan atas kepercayaan yang diberikan.

\section{Kinerja Keuangan}

\section{a. Pengertian Kinerja Keuangan`}

Menurut fahmi (2011:239), kinerja keuangan adalah suatu analisis yang dilakukan untuk melihat sejauh mana suatu perusahaan telah melaksanakan dengan menggunakan aturan-aturan pelaksanaan keuangan secara baik dan bener.

Menurut Jumingan (2014:239) kinerja keuangan adalah gambaran kondisi keuangan pada suatu periode tertetu baik menyangkut aspek penghimpunan dana maupun penyaluran dana yang biasanya diukur dengan indikator kecukupan modal, likuiditas, dan profitabilitas.

Kinerja keuangan suatu perusahaan dapat diartikan sebagai prospek atau masa depan, pertumbuhan dan potensi perkembangan yang baik bagi perusahaan. Informasi kinerja keuangan diperlukan untuk menilai perubahan potensial sumber daya ekonomi, yang mungkin dikendalikan di masa depan dan untuk memprediksi kapasitas produksi dari sumber daya yang ada (Barlian, 2003).

Pimpinan perusahaan atau manajemen sangat berkepentingan terhadap laporan keuangan yang telah di analisis, karena hasil tersebut dapat dijadikan sebagai alat dalam pengambilan keputusan lebih lanjut untuk masa yang akan datang. Dengan menggunakan analisis rasio, berdasarkan data dari laporan keuangan, akan dapat diketahui hasilhasil finansial yang telah dicapai di waktuwaktu yang lalu, dapat diketahui kelemahan-kelemahan yang dimiliki perusahaan, 
serta hasil-hasil yang dianggap cukup baik.

\section{b. Tujuan Kinerja Keuangan}

Menurut Munawir (2000:31), tujuan penilaian kinerja keuangan adalah sebagai berikut:

1. Untuk mengetahui tingkat likuiditas, yaitu kemapuan perusahaan untuk memperoleh kewajiban keuangannya yang harus segera dipenuhi atau kemampuan perusahaan untuk memenuhi keuangannya pada saat ditagih.

2. Untuk mengetahui tingkat solvabilitas, yaitu kemampuan perusahaanuntuk memenuhi kewajiban keuangannya apabila perusahaan tersebut dilikuidasi baik kewajiban keuangan jangka pendek maupun jangkapanjang.

3. Untuk mengetahui tingkat rentabilitas atau profitabilitas, yaitu menunjukkan kemampuan perusahaan untuk menghasilkan laba selama periode tertentu.

4. Untuk mengtahui tingkat stabilitas usaha, yaitu kemampuan perusahaan untuk melakukan usahanya dengan stabil, yang dikur dengan mempertimbangkan kemampuan perusahaan untuk membayar beban bunga atas hutang-hutangnya termasuk membayar kembali pokok hutangnya tepat pada waktunya serta kemampuan membayar deviden secara teratur kepada para pemegang saham tanpa mengalami hambatan atau krisis keuangan.

\section{c. Pengukuran Kinerja Keuangan}

Pengukuran kinerja digunakan perusahaan untuk melakukan perbaikan diatas kegiatan operasionalnya agar dapat bersaing dengan perusahaan lain. Analisis kinerja keuangan merupakan proses pengkajian secara kritis terhadap review data, menghitung, mengukur, menginterprestasi, dan memberi solusi terhadap keuangan perusahaan pada suatu periode tertentu. 
Kinerja Keuangan dapat dinilai dengan beberapa alat analisis. Berdasarkan tekniknya, analisis keuangan dapat dibedakan menjadi 8 macam, yaitu menurut Jumingan (2006:242):

1.Analisis perbandingan Laporan Keuangan, merupakan teknik analisis dengan cara membandingkan laporan keuangan dua periode atau lebih dengan menunjukkan perubahan, baik dalam jumlah (absolut) maupun dalam persentase (relatif).

2. Analisis Tren (tendensi posisi), merupakan teknik analisis untuk mengetahui tendensi keadaan keuangan apakah menunjukkan kenaikan atau penurunan.

3. Analisis Persentase per Komponen (common size), merupakan teknik analisis untuk mengetahui persentase investasi pada masing-masing aktiva terhadap keseluruhan atau total aktiva maupun utang.

4. Analisis Sumber dan Penggunaan Modal Kerja, merupakan teknik analisis untuk mengetahui besarnya sumber dan penggunaan modal kerja melalui dua periode waktu yang dibandingkan.

5.Analisis Sumber dan Penggunaan Kas, merupakan teknik analisis untuk mengetahui kondisi kas disertai sebab terjadinya perubahan kas pada suatu periode waktu tertentu.

6.Analisis Rasio Keuangan, merupakan teknik analisis keuangan untuk mengetahui hubungan di antara pos tertentu dalam neraca maupun laporan laba rugi baik secara individu maupun secara simultan.

7. Analisis Perubahan Laba Kotor, merupakan teknik analisis untuk mengetahui posisi laba dan sebab-sebab terjadinya perubahan laba. 
8.Analisis Break Even, merupakan teknik analisis untuk mengetahui tingkat penjualan yang harus dicapai agar perusahaan tidak mengalami kerugian.

\section{d. Hubungan Kinerja Keuangan Dengan Analisis Laporan Keuangan}

Tingkat kesehatan merupakan alat ukur yang digunakan oleh pemakai laporan keuangan untuk mengukur kinerja suatu laporan keuangan tersebut. Dari laporan keuangan dapat diketahui keadaan financial dari hasil -hasil yang telah dicapai perusahaan selama periode tertentu. Tingkat kesehatan perusahaan dapat dikeathui melalui analisis atau interpretasi terhadap laporan keuangan. Dari hasil analisis dapat diketahui presentasi dan kelemahan yang dimiliki perusahaan, sehinggat dapat digunakan sebagai pertimbangan dalam pengambilan keputusan. Inteterpretasi atau analisis laporan keuangan suatu perusahaan adalah sangat penting bagi pihak - pihak yang berkepentingan.

Secara umum Saraswati (2013:4) mengemukakan bahwa ada lima tahap dalam menganalisis kinerja keuangan suatu perusahaan yaitu:

1. Melakukan review terhadap data laporan keuangan

2. Melakukan perhitungan

3. Melakukan perbandingan terhadap hasil hitungan yang diperoleh

4. Melakukan penafsiran (interpretasi) terhadap berbagai permasalahn yang ditemukan

5. Mencari dan memberikan pemecahan masalah (solusi) terhadap berbagai permasalahan yang ditemukan.

Jadi dapat disimpulkan bahwa kinerja perusahaan yang tergambar dalam laporan keuangan yang menjadi perhatian utama bagi para pemakai laporan 
keuangan tersebut. Oleh karena itu manajemen perusahaan perlu mengusahakan untuk meningkatkan kinerja dari periode ke periode.

\section{Analisis Rasio Keuangan}

\section{a. Pengertian Analisis Rasio Keuangan}

Rasio keuangan merupakan alat analisis untuk menjelaskan hubungan tertentu antara elemen yang satu dengan elemen yang lainnya dalam suatu laporan keuangan (financial statement). Analisis rasio keuangan merupakan salah satu teknik dalam menganalisis laporan keuangan untuk menilai kinerja keuangan suatu perusahaan dengan menghubungkan berbagai perkiraan yang terdapat pada laporan keuangan dalambentuk rasio keuangan yang menjelaskan kepada penganalisis mengenai keadaan atau posisi keuangan suatu perusahaan.

Pengertian Analisis rasio keuangan menurut Subramanyam dan Wild (2012:4) yaitu: Analisis rasio keuangan adalah Bagian dari analisis bisnis atas prospek dan risiko perusahaan untuk kepentingan pengambilan keputusan dengan menstrukturkan tugas analisis melalui evaluasi atas bisnis lingkungan perusahaan, strateginya, serta posisi dan kinerja keuangannya.

Menurut Munawir (2010:64) Analisis rasio keuangan adalah: Analisis rasio keuangan adalah rasio yang menggambarkan suatu hubungan atau pertimbangan (mathematical relationship) antara suatu jumlah tertentu dengan jumlah yang lain, denganmenggunakan alat analisa berupa rasio yang menjelaskan gambaran kepada penganalisa tentang baik atau buruk keadaan keuangan perusahaan terutama apabila angka rasio tersebut dibandingkan dengan angka rasio pembanding yang digunakan sebagai standar. 


\section{b. Rumus Rasio Keuangan}

\section{Rasio Profitabilitas}

Jenis Berbagai jenis ini menilai dengan ukuran yang berbeda untuk Menurut Sunyoto (2013:113), pengertian rasio profitabilitas adalah kemampuan perusahaan untuk memperoleh keuntungan dari usahanya. Menurut Sugiono dan Untung (2016: 66), rasio profitabilitas bertujuan untuk mengukur efektifitas manajemen yang tercermin pada imbalan atas hasil investasi melalui kegiatan perusahaan atau mengukur kinerja perusahaan secara keseluruhan dan efisiensi dalam pengelolaan kewajiban dan modal.

Rasio ini memiliki beberapa tujuan dan manfaat menurut Kasmir (2016), antara lain ;

1. Untuk mengukur atau menghitung laba yang diperoleh perusahaan dalam satu periode tertentu.

2. Untuk menilai posisi laba perusahaan tahun sebelumnya dengan tahun sekarang.

3. Untuk mengetahui perkembangan laba dari waktu ke waktu.

4. Untuk menilai besarnya laba bersih sesudah pajak denganmodal sendiri.

Rasio profitabilitas terdiri dari beberapa menghasilkan informasi mengenai kemampuan perusahaan dalam menghasilkan profit. Jenis-jenis tersebut antara lain:

\section{Gross Profit Margin}

Home dan Wachowiccz (2012) menjelaskan bahwa rasio ini memberi tahu kita laba dari perusahaan yang berhubungan dengan penjualan setelah kita mengurangi biaya untuk memproduksi barang yang dijual.Menurut Sugiono dan Untung (2016:66) menjelaskan bahwa rasio ini menunjukkan harga besar keuntungan kotor yang dijual dari menjual produk.

$$
\text { Gross Profit Margin }=\frac{\text { Laba Kotor }}{\text { Penjualan }} \times 100 \%
$$

\section{Net Profit Margin}

Menurut Sugiono dan Untung (2016:67) mengemukakan bahwa "rasio ini 
menunjukkan berapa besar keuntungan bersih yang diperoleh perusahaan. Jika Net profit margin suatu perusahaan lebih rendah dari rata-rata industrinya, maka hal ini dapat disebabkan oleh harga pokok penjualan lebih tinggi dari perusahaan pesaingatau kedua-duanya."

$$
\text { Net Profit Margin }=\frac{\text { Laba Bersih }}{\text { Penjualan Bersih }} \times 100 \%
$$

Besarnya persentase keuntungan baik laba kotor maupun laba bersih bergantung pada jenis usaha perusahaan, untuk perdagangan biasanya mempunyai persentase laba lebih kecil dibandingkan dengan persentase laba perusahaan manufaktur. Hal ini disebabkan faktor resiko, di mana perusahaan perdagangan mempunyai resiko lebih kecil dibandingkan dengan perusahaan manufaktur.

\section{Return on Asset}

Danuarta (2014) mengatakan bahwa return on asset adalah kemampuan suatu perusahaan dengan seluruh modal yang bekerja di dalamnya untuk menghasilkan laba operasi perusahaan atau laba sebelum bunga dan pajak.

$$
\text { Return on Asset }=\frac{\text { Laba Bersih }}{\text { Total Aktiva }} \times 100 \%
$$

Presentase rendah sebagai hasil dari perhitungan ini memberikan informasi bahwa kurangnya kinerja perusahaan dari segi pemanfaatan aset untuk menghasilkan laba. Langkah yang dapat diambil oleh perusahaan untuk meningkatkan persentase ini salah satunya dengan meningkatkan pendapatan atau menekan biaya-biaya operasi.

\section{Return on Equity}

Menurut Sugiono dan Untung (2016:68) rasio ini mengukur tingkat pengembalian dari bisnis atas seluruh modal yang ada. ROE merupakan slaah satu indikator yang digunakan pemegang saham untuk mengukur keberhasilan bisnis yang dijalani. Rasio ini dapat disebut juga dengan rentabilitas modal sendiri.

$$
\text { Return on Equity }=\frac{\text { Laba Bersih }}{\text { Total Ekuitas }} \times 100 \%
$$

Return on Equity yang tinggi sering kali mencerminkan penerimaan perusahaan atas peluang investasi yang baik dan manajemen biaya yang efektif. Semakin 
tingginya presentase dari rasio ini juga memberikan manfaat berupa semakin kuatnya posisi pemilik modal perusahaan.

\section{Rasio likuiditas}

Menurut Hanafi dan Halim (2016:75), rasio likuiditas adalah "rasio yang mengukur kemampuan likuiditas jangka pendek perusahaan dengan melihat aktiva lancar perusahaan relatif terhadap utang lancarnya (utang dalam hal ini adalah kewajiban perusahaan)." Meskipun rasio ini tidak bicara masalah solvabilitas (kewajiban jangka panjang), dan biasanya relatif tidak penting dibandingkan rasio solvabilitas, tetapi rasio likuiditas yang jelek dalam jangka panjang juga akan mempengaruhi solvabilitas perusahaan. Dua rasio likuiditas jangka pendek yang sering digunakan adalah rasio lancar dan rasio quick(acid test ratio).

Menurut Raharjaputra (2009:199) rasio likuiditas ini sebenarnya paling banyak mendapat perhatian dari para analisis mampu investor. Walaupun analisis terhadap likuiditas ini membutuhkan bantuan lain, namun penggunaan rasio ini terbilang cepat dan mudah.Adapun tujuan dan manfaat rasio likuiditas ;

a. Untuk mengukur kemampuan perusahaan membayar kewajiban atau utang yang segera jatuh tempo pada saat ditagih. Artinya, kemampuan untuk membayar kewajiban yang sudah waktunya dibayar sesuai jadwal batas waktu yang telah ditetapkan.

b. Untuk mengukur kemampuan perusahaan membayar kewajiban jangka pendek dengan aktiva secara keseluruhan. Artinya, jumlah kewajiban yang berumur di bawah satu tahun atau sama dengan satu dengan satu tahun dibandingkan dengan total aktiva lancar.

c. Untuk mengukur kemampuan perusahaan membayar kewajiban jangka pendek dengan aktiva lancar tanpa memperhitungkan sediaan atau piutang, dalam hal ini aktiva lancar dikurangi sediaan dan utang yang dianggap likuiditasnya lebih rendah.

d. Untuk mengukur atau membandingkan antara jumlah sediaan yang ada dengan modal kerja perusahaan. 
e. Untuk mengukur seberapa besar uang kas yang tersedia untuk membayar utang. Sedangkan alat perencanaan ke depan, terutama yang berkaitan dengan perencanaan kas dan utang.

f. Untuk melihat kondisi dan posisi likuiditas perusahaan dari waktu ke waktu dengan membandingkan untuk beberapa periode.

g. Untuk melihat kelemahan yang dimiliki perusahaan, dari masing-masing komponen yang ada di aktiva lancar dan utang lancar.

h. Menjadi alat pemicu bagi pihak manajemen untuk memperbaiki kinerjanya, dengan melihat rasio likuiditas yang ada pada saat ini.

Adapun jenis rasio likuditas yang dianalisis meliputi ;

\section{Current ratio (rasio lancar)}

Aktiva lancar menggambarkan alat bayar dan diasumsikan semua aktiva lancar benar-benar bisa digunakan untuk membayar. Sedangkan utang lancar menggambarkan yang harus dibayar dan diasumsikan semua utang lancar benarbenar dibayar. Current ratio sangat berguna untuk mengukur likuiditas perusahaan, akan tetapi dapat menjebak.

Hal ini dikarenakan current ratio yang tertinggi dapat disebabkan oleh adanya piutang yang tidak tertagih atau persediaan yang tidak terjual, yang tentu saja tidak dapat dipakai untuk membayar utang. Untuk menguji apakah alat bayar tersebut benar-benar likuid (benar-benar dapat digunakan untuk membayar utangnya), maka alat bayar yang kurang atau tidak likuid harus dikeluarkan dari total aktiva lancar. Alat bayar yang kurang likuid ini misalnya persediaan dan pospos yang analog dengan persediaan (Dwi dan Rifka. 2008:85).

Rasio yang menunjukkan adanya kelebihan aktiva lancar, yang akan mempunyai pengaruh yang tidak baik menghasilkan terhadap profitabilitas perusahaan. Aktiva lancar secara umum menghasilkan return yang lebih rendah dibandingkan dengan aktiva tetap. Rasio ini dapat dihitung dengan rumus:

$$
\text { Current Ratio }=\frac{\text { Aktiva Lancar }}{\text { Hitung Lancar }}
$$

Aktiva lancar (current assets) merupakan harta perusahaan yang dapat 
dijadikan uang dalam waktu singkat (maksimal satu tahun). Komponen aktiva lancar meliputi kas, bank, surat-surat berharga, piutang, sediaan, biaya dibayar dimuka, pendapatan yang masih harus diterima, pinjaman yang diberikan dan aktiva lancar lainnya.

Hutang lancar (current liabilities) merupakan kewajibanperusahaan jangka pendek (maksimal satu tahun). Artinya, utang ini segera harus dilunasi dalam waktu paling lama satu tahun. Komponen utang lancar terdiri dari utang dagang, utang bank atau tahun, utang wesel, utang gajih, utang pajak, utang dividen, biaya diterima dimuka, utang jangka panjang yang sudah hampir jatuh tempo, serta utang jangka pendek lainnya.Rumus current ratio menurut Sugiono dan Untung (2016):

$$
\text { Current Ratio }=\frac{\text { Aktiva Lancar }}{\text { Hitung Lancar }} \times 100 \%
$$

Pada kenyataannya, current ratio yang terlalu tinggi juga dianggap tidak baik. Fahmi (2011) menyebutkan terdapat indikasi masalah dari nilai current ratio yang ekstrim, antara lain;

a.Penimbunan kas,

b.Banyaknya piutang yang tidak tertagih.

c.Penumpukan persediaan.

d.Tidak efisiensinya pemanfaatan pembiayaan gratis dari pemasok.

e.Rendahnya pinjaman jangka pendek.

Meski memang nilai current ratio yang relatif rendah akan meningkatkan kekhawatiran yang lebih besar, tetapi dapat menjadi ukuran kinerja manajemen perusahaan telah berjalan secara efektif.

\section{Quick Ratio}

Menurut Sunyoto (2013:90) quick ratio adalah "rasio hasil perbandingan antara kas dan aktiva lancar (quick assets) dengan utang lancar atau utang jangka pendek.Rumus quick ratio menurut Sugiono dan Untung (2016:58) ;

$$
\text { Quick Ratio }=\frac{\text { Total Aktiva Lancar }- \text { Persediaan }}{\text { Total Kewajiban Lancar }} \times 100 \%
$$

\section{Cash Ratio}


Menurut Sugiono (2016:58) bahwa "kas ratio merupakan perbandingan antara kas yang ada di perusahaan di bank (termasuk surat berharga seperti deposito) dibandingkan dengan total hutang lancar." Sedangkan menurut Sunyoto (2013:91) cash ratiomenunjukkan kemampuan perusahaan dalam memenuhi kewajiban jangka pendeknya dengan uang kas dan surat berharga yang mudah diperdagangkan, yang tersedia di dalam perusahaan.Rumus cash ratio menurut Sugiono dan Untung (2016:58):

$$
\text { Cash Ratio }=\frac{\text { Kas }}{\text { Total Kewajiban Lancar }} \times 100 \%
$$

\section{Rasio aktivitas}

Handoyo (1997:34) menyatakan bahwa "Rasio Aktivitas yaitu rasio yang menunjukkan kemampuan perusahaan dalam mendayagunakan aktivanya". Menurut Kasmir (2008:172) "rasio Aktivitas merupakan rasio yang digunakan untuk mengukur efektivitas perusahaan dalam menggunakan aktiva yang dimilikinya". Rasio aktivitas juga dapat mengukur kemampuan perusahaandalam melaksanakan aktivitas sehari-hari. Hal ini dapat mengetahui apakahperusahaaan lebih efektif dan efisien dalam mengelola asset yang dimilikinya.

Dari beberapa pendapat di atas dapat disimpulkan bahwa rasio Aktivitas yaitu kemampuan perusahaan dalam mengelola atau mendayagunkan aset yang dimilikinya baik secara harian ataupun selama periode tertentu. Berikut beberapa jenis-jenis rasio Aktivitas, yaitu:

\section{a. Inventory Turnover ( Perputaran Persediaan)}

Munawir (2004:77) Menyatakan bahwa “Inventory Turnover ( Perputaran Persediaan) adalah merupakan rasio antara jumlah harga pokok barang yang 
dijual dengan nilai rata-rata persediaan yang dimiliki perusahaan”. Menurut Kasmir (2008) "Inventory Turnover merupakan rasio yang menunjukan berapa kali jumlah barang persediaan diganti dalam satu tahun”. Dengan kata lain dapat dijelaskan bahwa Inventory Turnover adalah kemampuan perusahaan dalam pergantian persedian yang tersedia di perusahaan tersebut. Secara sistematis dapat dirumuskan sebagai berikut:

$$
\text { Inventory Turnover }=\frac{\text { Harga pokok penjualan }}{\text { Persediaan }}
$$

Rasio ini menunjukkan seberapa cepat perputaran persediaan dalam siklus produksi normal. Semakin besar rasio ini semakin baik, karena dianggap bahwa kegiatan penjualan berjalan cepat.

\section{b. Fixed Assets Turnover (Perputaran Aktiva Tetap)}

Fixed Assets Turnover (Perputaran Aktiva Tetap) merupakan perbandingan antara penjualan bersih dengan aktiva tetap. Fixed Assets Turnover merupakan rasio yang digunakan untuk mengukur berapa kali dana yang ditanamkan dalam aktiva tetap berputar dalam satu periode. Secara sistematis dapat dirumuskan sebagai berikut:

$$
\text { Fixed Assets Turnover }=\frac{\text { Penjualan bersi } 10}{\text { Aktiva tetap }}^{\text {A }} 100
$$

Rasio ini menunjukkan berapa kali nilai aktiva berputar bila diukur dari volume penjualan. Semakin tinggi rasio ini semakin baik, karena kemampuan aktiva tetap menciptakan penjualan tingg 


\section{Rasio solvabilitas}

Menurut Weston (Kasmir, 2016:150), "rasio solvabilitas merupakan rasio yang digunakan untuk mengukur sejauh mana aktiva perusahaan dibiayai dengan utang dan untuk mengukur kemampuan perusahaan dalam membayar seluruh kewajibannya, baik jangka pendek maupun jangka panjang apabila perusahaan dilikidasi (dibubarkan). Rasio yang digunakan meliputi:

\section{Rasio Hutang Terhadap Aktiva (Total Debt to Asset Ratio)}

Rasio ini mengukur seberapa besar aktiva perusahaan yang dibiayai oleh utang atau seberapa besar hutang perusahaan dapat berpengaruh terhadap pengelolaan aktiva. Rumusnya adalah ;

$$
\text { Debt to Assets Ratio }=\frac{\text { Total Hutang }}{\text { Modal Aktiva }} \times 100 \%
$$

\section{Rasio Hutang Terhadap Ekuitas (Total Debt to Equity Ratio)}

Rasio ini akan menunjukkan hubungan antara jumlah utang jangka panjang dengan jumlah modal sendiri yang diberikan oleh pemilik perusahaan, untuk mengetahui jumlah dana yang disediakan kreditor dengan pemilik perusahaan.

Debt to Equity Ratio $=\frac{\text { Total Hutang }}{\text { Modal Sendiri }} \times 100 \%$

Adapun tujuan dan manfaat rasio solvabilitas, yaitu:

Menganalisis status perusahaan dan kemampuannyadalammemenuhikewajibannya pada pihak ketiga.

$>$ Mengetahuistatus perusahaan dengan melihatkeseimbanganantara jumlah modal dan aktiva tetap yangdimiliki.

Mencari tahu berapa besarnya rupiah dari modal sendiriyang akan digunakan sebagai jaminan pembayaran utangjangka panjang.

> Untuk melihat sejauhmana pengaruh utangyangditanggung perusahaan terhadap pengelolaan aktiva yang ada.

Seberapa banyak aset atau aktiva yang dimilki oleh perusahaan dapat mencerminkan kondisi operasional perusahaan. Semakin banyak aktiva yang 
dimilikinya maka semakin tinggi kemampuan perusahaan tersebut dalam melunasi utang yang dimilikinya. Sebaliknya, jumlah aktiva yang sedikit akan menyusahkan perusahaan dalam melunasi utang-utang yang ditanggungnya. Rasio solvabilitas biasanya diperlukan ketika perusahaan akan tutup untuk memastikan bahwa ia bisa melunasi utang-utangnya atau tidak.

\section{B. Kerangka Pikir}

Kerangka pikir dalam penelitian ini dinyatakan dalam bentuk skema sebagai berikut

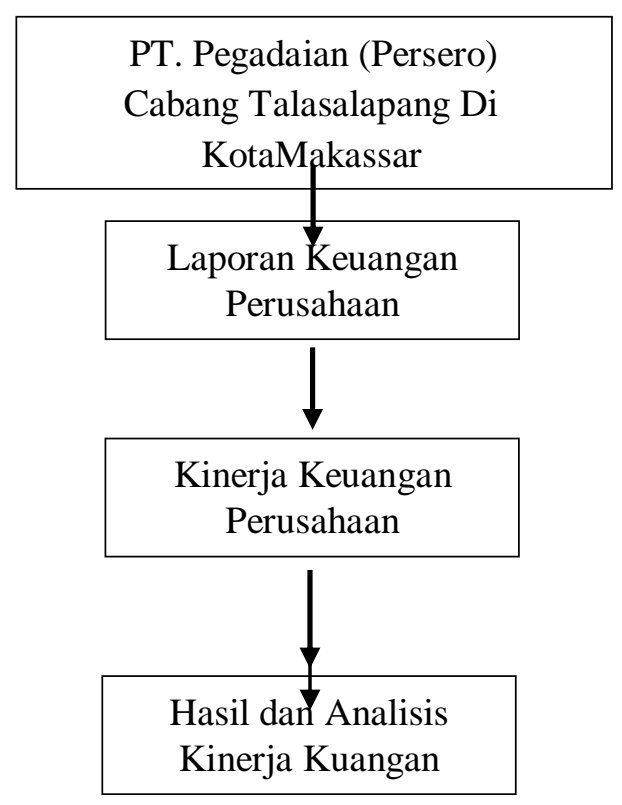

Gambar 1 : Kerangka Pikir 


\section{Hipotesis Penelitian}

Hipotesis merupakan jawaban sementara terhadap rumusan masalah penelitian, oleh karena itu, maka hipotesis yang diajukan dalam penelitian ini adalah : " kinerja keuangan yang dicapai oleh PT. Pegadaian (Persero) Cabang Talasalapang Di Kota Makassar selama lima tahun terakhir (2015-2019) mengalami peningkatan ". 


\section{DAFTAR PUSTAKA}

Daga, R. (2021). Pengaruh Pelaksanaan Program Pemeliharaan Karyawan Terhadap Loyalitas Karyawan Pada Pt. Bank Sulselbar Kantor Pusat Makassar.

Fahmi Irham, 2011. Analisis Kinerja Keuangan, Jakarta: CV. Alfabeta.

Kasmir, 2008. Analisis Laporan Keuangan, Rajawali Grafindo Persada, Jakarta

Munawir, 2007, Analisa Laporan Keuangan. Edisi Empat. Yogyakarta: PT Liberty.

Muslich, Mochammad.2003. Manajemen Keuangan Modern Analisis, Perencanaan dan Kebijaksanaan. Cetakan Ketiga. PT Bumi Aksara.Jakarta.

Pramita, Y., \& Afriyeni, A. (2019). Analisis Rasio Keuangan Pada PT.

Pegadaian (Persero) Cabang Ulak Karang.

Standar Akuntansi Keuangan No.1 (2002:13), Laporan Keuangan 